RESIDENT

\& FELLOW

SECTION

Section Editor

Mitchell S.V. Elkind,

MD, MS

R. Nandhagopal, MBBS, DM

A. Al-Asmi, MD, FRCPC F. Al-Azri, MD, FRCPC

P.C. Jacob, MBBS, $\mathrm{MD}, \mathrm{DM}$

G.R. Arunodaya, MBBS, DM

A. Alobaidy, MD

Address correspondence and reprint requests to Dr. R. Nandhagopal, College of Medicine and Health Sciences, P.O. Box. 35, SQU, Al-Khod, Zip 123, Muscat, Oman rnandagopal@yahoo.com

\title{
Teaching NeuroImages: \\ Vestibular schwannomas in neurofibromatosis type 2
}
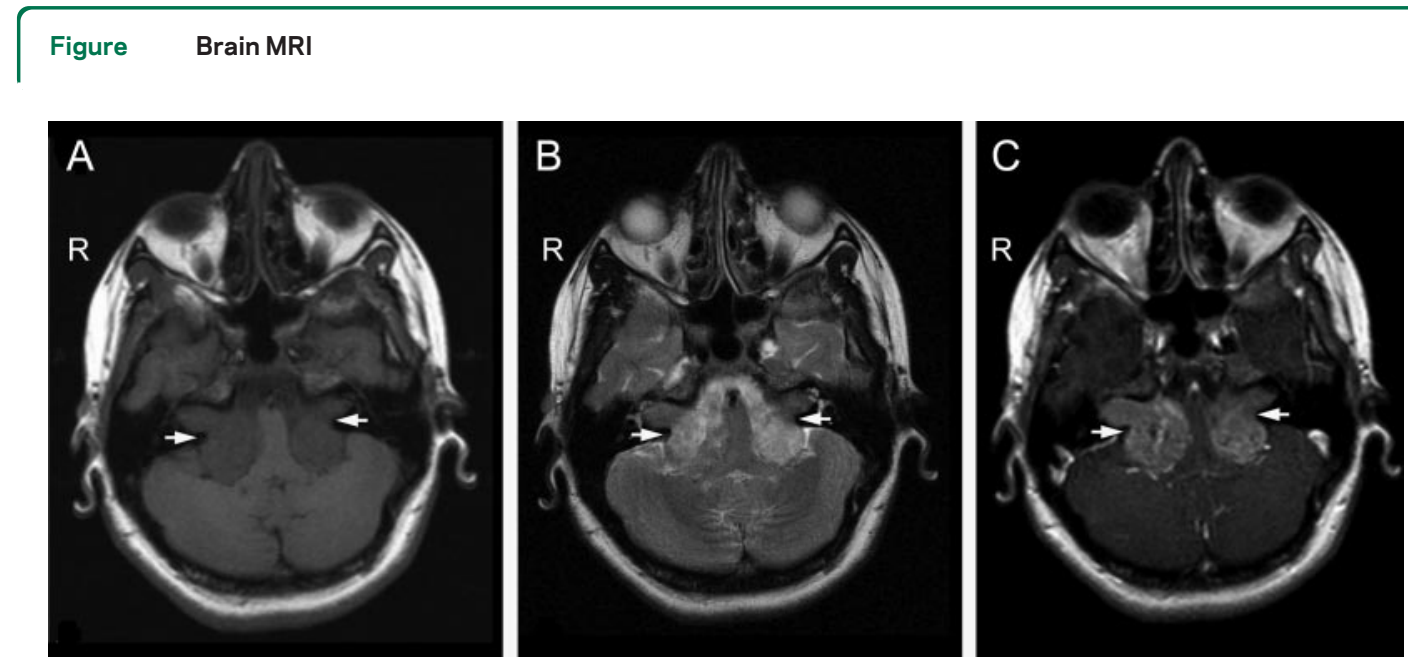

MRI brain (A-C) demonstrating bilateral vestibular schwannomas (acoustic neuromas, arrows) compressing the pontomedullary region. These extraaxial lesions (arrows) are hypointense on T1-weighted axial image (A), are hyperintense on T2weighted axial image (B), and show enhancement after gadolinium administration on postcontrast T1-weighted image (C).

An 18-year-old woman with a history of juvenile cataract and hearing impairment presented with gait ataxia of 2 years' duration and demonstrated bilateral pyramidal signs in the legs. Brain MRI (figure) revealed extraaxial lesions in the cerebellopontine angles with brainstem compression. These bilateral vestibular schwannomas were pathognomonic of neurofibromatosis type 2 (NF2). ${ }^{1}$ In addition, there were multiple spinal tumors that could also account for the pyramidal signs.

The estimated birth incidence of NF2 is 1 in 25,000. ${ }^{2}$ Unlike neurofibromatosis type 1, these patients do not demonstrate extensive cutaneous findings. A positive family history along with the presence of juvenile cataract and hearing impairment provide clinical clues for triaging patients for early neuroimaging to establish the diagnosis before the onset of brainstem compression.

\section{REFERENCES}

1. Baser ME, Friedman JM, Wallace AJ, Ramsden RT, Joe H, Evans DG. Evaluation of clinical diagnostic criteria for neurofibromatosis 2. Neurology. 2002;59:17591765 .

2. Evans DG, Moran A, King A, Saeed S, Gurusinghe N, Ramsden R. Incidence of vestibular schwannoma and neurofibromatosis 2 in the North West of England over a 10year period: higher incidence than previously thought. Otol Neurotol 2005;26:93-97. 


\section{Neurology}

Teaching NeuroImages: Vestibular schwannomas in neurofibromatosis type 2 R. Nandhagopal, A. Al-Asmi, F. Al-Azri, et al. Neurology 2010;75;e60

DOI 10.1212/WNL.0b013e3181f61367

\section{This information is current as of October 4, 2010}

\section{Updated Information \&} Services

References

Subspecialty Collections

Permissions \& Licensing

Reprints including high resolution figures, can be found at: http://n.neurology.org/content/75/14/e60.full

This article cites 2 articles, 1 of which you can access for free at: http://n.neurology.org/content/75/14/e60.full\#ref-list-1

This article, along with others on similar topics, appears in the following collection(s):

MRI

http://n.neurology.org/cgi/collection/mri

Nerve tumor

http://n.neurology.org/cgi/collection/nerve_tumor

Information about reproducing this article in parts (figures,tables) or in its entirety can be found online at:

http://www.neurology.org/about/about_the_journal\#permissions

Information about ordering reprints can be found online:

http://n.neurology.org/subscribers/advertise

Neurology ${ }^{\circledR}$ is the official journal of the American Academy of Neurology. Published continuously since 1951, it is now a weekly with 48 issues per year. Copyright . All rights reserved. Print ISSN: 0028-3878. Online ISSN: 1526-632X.

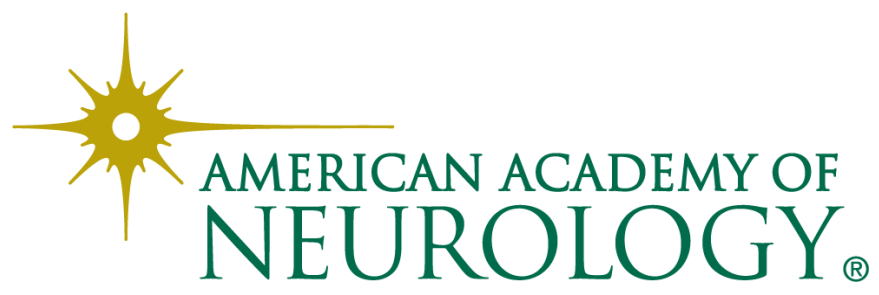

